\title{
ETHICS OF THE CIVIL SERVICE
}

\author{
V.S. Mukhametzhanova \\ Peoples' Friendship University of Russia (RUDN University) \\ 6, Miklukho-Maklaya St., 117198, Moscow, Russian Federation
}

\begin{abstract}
The article reviews the concept of the civil servant ethics as a separate type of professional ethics. According to the author's opinion, the problems of the civil service management and search for mechanisms to increase its effectiveness are extremely important for the modern society.

The specifics of the ethics of public service are determined by a number of factors. First, it is the special purpose of the state service itself, stipulated in the Constitution of the Russian Federation. Secondly, it is the special social and legal status of civil servants. Thirdly, these are the restrictions and obligations for the citizens of the Russian Federation while doing civil service. Fourth, it is the formation of effective human resources capacity of civil servants. Finally, it is the awareness of the high level of social responsibility of officials for the decisions taken in professional activities.

The article pays special attention to the analyzes of the ethical code aimed to increase the efficiency of the performance of duties by state officials. Awareness and observance of ethical principles are the key to assessing quality of their professional activities and behavior. Approved ethical principles of civil service set the common guidelines, ensuring the integrity and viability of the service as a system.
\end{abstract}

Key words: professional ethics, ethics of civil service, ethical code, ethical principles

Professional ethics as a part of the general ethical theory differs with its applied nature. One of its most important tasks is the concretization of general ethical regulators of human practical activity related to a profession. The main point of the moral assessment of professional activity and the personality of the employee is professionalism, which includes the moral appearance of a specialist, the comprehension and fulfillment of professional ethics requirements, the ability to be guided by universal and professional moral standards. Today, in the conditions of the transformation of society, professional ethics becomes the theoretical basis for the development of a person's moral culture.

Public interest to the importance of moral issues in the human culture history and to striving to understand the essence of moral and ethical issues at the level of modern knowledge is logical. Development of Russia aimed at the democratic state, the regulation of all its social structures is impossible without the establishment of ethical standards in all spheres of society.

Management is a complex process since it always involves two subjects of activity: person - person. Making the importance of the moral aspect of managerial activity stronger actualizes the problem of developing a special kind of professional ethics, which is administrative ethics. The ethics of the civil service represents the foundation of the service culture of officials at all levels of government, which codifies ethical principles, norms, prohibitions, rules of official conduct of civil servants acting as intermediaries in relationship between the state and its citizens. 
The peculiarity of the ethics of civil servants as a form of professional ethics is determined by different factors.

First, the specifics of the purpose of the civil service is fixed in Article 3 of the Constitution of the Russian Federation [5]. The 1993 Constitution determined the tactics and strategy of building a legal, social, democratic state, predetermining the goals, objectives and content of the qualitative characteristics of its authorized representative, that is the civil service.

Secondly, it is a special social and legal status of civil servants. Civil service as a social and legal institution takes a special place in the achievement of national goals and plays an important role in the governmental mechanism. Formation and determination of the state civil service in Russia, called to serve to a society and citizens is the important condition of effective functioning of the state.

Thirdly, the restrictions and obligations established by Federal Law No. 79-FZ of July 27, 2004 "On the Civil Service System of the Russian Federation" during the civil service (the presence of Russian citizenship, persons who have reached the age of 18 , higher profile education, 3 years, etc.) [11].

Fourth point is the volume and content of the competence and the level and contents of responsibility for the quality and social consequences of their professional activities. Formation of effective human resources in the professional work of civil servants is a key factor for providing strength and high efficiency of the government. In 2009, the Federal Program No. 261 "Reforming and developing the civil service system of the Russian Federation" was approved by the Presidential Decree [10]. This program was aimed at creating, implementing and improving mechanisms to comply with the requirements for civil servants conduct and the conflict of interest in the civil service; as well as the development of procedures for dealing with cases of unethical behavior of civil servants.

The state civil service is a professional service activity of a certain contingent of officials (employees) for ensuring the execution of the powers of state power structures. This service gives direction to the activities of government bodies and, in the course of implementing the competence of these bodies, preserves and provides this direction.

In other words, the civil service plays the role of a steersman in the practical execution of powers, helping the state achieve the goals determined by the country's political leadership. Entry into the service (that is, the replacement of a post) implies decent conduct, a developed sense of responsibility, honor, honesty and duty, so the requirement to the employees to observe moral norms is very important.

According to the established duty, the civil servant must selflessly, unselfishly, conscientiously perform professional duties and duties. His conduct within and outside the service must be such that it does not damage the respect and confidence of the society and citizens which his profession requires [7. P. 34-37].

The professional ethics of public service as a scientific direction studies the influence of morality on the work of the apparatus of the public authority and seeks answers to questions about what is right and what is wrong in the behavior of employees and what must be done to form high moral principles. The professional ethics of the civil service, along with psychological, pedagogical, economic, managerial and other compo- 
nents, is a very important component in the corporate (professional) culture of state civil servants. It is worth reminding that ethical standards of service are more precise than ordinary moral standards.

Professional ethics of the civil service as a regulator of the corps of officials is able to maintain the effectiveness of management activities and contribute to the growth of its effectiveness, which allows us to supersede motivation through coercion, which elements are the part of the service concept. Thus, ethics of the civil service suggests to characterize the position and behavior of the employee in terms of his assessment, regulation and consequences. This makes it possible not to lose the personality when it is hidden behind the service instructions.

Even more attention is paid to the study of ethical standards and norms of behavior of management staff. This, Department of the State Service of the Ministry of Health and Social Development of Russia in December 2010 approved the "Model Code of Ethics and Official Conduct of Civil Servants of the Russian Federation and Municipal Employees". The concept of the code is defined as "a set of general principles of professional service ethics and basic rules of official conduct, which should be guided by the civil servant of the Russian Federation and the municipal employee, regardless of the position being replaced". This ethical code is designed to increase the effectiveness of the performance of government officials in their official duties. Knowledge and observance of the provisions of the Code by the civil servant is one of the criteria for assessing the quality of his professional activities and performance. Thus, this code is "a set of rules for self-sufficiency, the fulfillment of which serves as a guarantee of successful labor and productive work" [8].

Formed and approved ethical principles of service in the "Model Code of Ethics and Official Conduct of Civil Servants of the Russian Federation and Municipal Employees" provide common guidelines, ensuring the integrity and viability of service as a system and expressing its supreme values. These regulations define them, prescribe a certain style of behavior, contain restrictions, recommendations, prohibitions and guarantee that people can rely on each other for achieving common goals and avoiding conflicts.

The Code of Ethics for Civil Servants is a systematized list of ethical principles, norms and rules that express the moral requirements of society for the moral personality of a civil servant, the social purpose of his activities and the nature of the relationship with society, citizens and the state in his professional environment. As any other code, it contains norms which "reflect existing social relations... are produced by social needs, by the level of working morality development, by the specificity of professional functions" [9. P. 491].

The professional ethics of civil service as a system of ethical norms and the science of their application in management performs a very essential function. No matter how optimal the legal standards regulating labor relations are, they can lose effectiveness because of unscrupulous employees' activity. That is why it is important that legal standards be supplemented also with moral ones.

It should be pointed out that the norms of professional ethics extend to those areas of official activity that cannot be resolved by law. The right cannot prevent the mani- 
festation of such negative personal qualities of employees, as arrogance, servility, rudeness, indifference. The manifestation of these qualities can only be influenced by moral triggers [3. P. 14 -23]. For example, the rules of criminal law provide for the severe responsibility of employees to receive bribes, and moral norms condemn any grasping desire of employees of the administrative apparatus with the use of official position.

A special feature of the professional ethics of the civil service can be the fact that it acquires some features of a formalized state while training in the moral principles of activity is more and more actualized. In addition, currently high level of public awareness of governance requires that the public service comply with the ethical code, which becomes an integral part of the management system itself.

The basics of the professional ethics of civil service can be understood and studied on the basis of an analysis of three levels:

1) the national level of public service as public legal institutions and carriers of a specific corporate culture;

2) the level of the state body, whose style of work is normalized from a set of stable patterns of values and legal norms, accumulated traditions, experience and modern orientation;

3) the level of the personality of the civil servant, whose individual culture accommodates a combination of professional qualities and properties, beliefs, knowledge and skills, a definite set of managerial technologies.

The manifestation of corporate consciousness by following the principles of professional ethics is a favorable condition for improving the work of governmental machinery aimed at conscientious and effective performance by employees of official (service) duties [2. P. 14; 4. P. 96-115].

The principle of public service, stemming from the provisions of the Constitution of the Russian Federation on the social character of the Russian state, is based on the systematization of the ethical principles of official conduct of civil servants as the fundamental requirements to the moral essence and social purpose of their professional activity, to which they must adhere during performing their official duties.

Implementing of the power through the government, people as the carrier of sovereignty and the only source of power in the Russian Federation oblige authorities to call, observe and protect the rights and freedoms of man and citizen, create conditions that ensure a decent life and free development of a person.

Being an institution for the implementation of state policy and its obligations to society, and therefore fulfilling the mission of public service, the staff corps of employees is to meet the requirements and social expectations of citizens, that is, taxpayers who provide their labor and have the right to demand from them honest and conscientious fulfillment of their Civil and official duty.

Another important ethical principle of the Russian civil servant is the principle of legality of the supremacy of the Constitution of the Russian Federation and federal laws over all other normative acts and duty descriptions [1].

The embodiment of this principle in life and managing it in direct practical work acts as the determining social and spiritual basis for staff management. 
In a civil servant's practice, there is often a moral problem: how to be an official who received an illegal order from his superior leader, from his point of view? Practice shows that the principle of legality is not always respected. The reasons are the social insecurity of the civil servant, his dependence on his superiors, the low level of legal culture, the instability of personal values and so-called "flexible" conscience.

The ethical principle of humanism requires from the state and municipal employee respect for the person, faith in him, recognition of the sovereignty and dignity of the individual. However, the requirement of a humane, respectful attitude towards a person is mostly ignored by many modern Russian civil servants. Consequently, low professional culture, deformation of feelings, needs, motives and ideals continue the manifestation of moral deformation of employees [6].

The principle of impartiality and independence should, first of all, provide the civil servant the service to the interests of the state and society in a situation of moral choice in the development and implementation of a concrete decision. State employees should not use state property and official information for non-official purposes.

In the conditions of corruption of the state machinery, civil servants do not pay much attention to the principle of impartiality and independence, and they are more concerned with the issued related to personal well-being than with state and public interests.

The principle of responsibility emphasizes that any administrative authority is responsible for the negative consequences of decisions, failure to perform its official duties, actions that violate the rights and legitimate interests of citizens. Civil servants, aware of their responsibility to the society and its citizens, have a civil conscience, professional honesty, a heightened sense of duty, honor and dignity, manifested in the unity of the word and deed.

Normal work of a civil servant is impossible if it is not based on the principle of justice, realizing itself in the effective protection of the rights of citizens, as well as in the lawful use of power and meeting social expectations of society. Any injustice, allowed by an official, does not discredit just him, but also authorities in general, causing them irreparable moral damage.

The requirements of the code should serve as the main criteria for ethical assessment of the quality of professional activity and official behavior of civil servants. Therefore, steady observance of the principles of public service, legality, humanity, impartiality, responsibility, justice by civil servants testifies to the so-called moral health of the state. Thus, they form the basis of the ethics of public service, ensuring its integrity and effectiveness.

(C) Mukhametzhanova V.S., 2017

\section{ENDNOTES}

(1) Look up in "Model Code of Ethics and Official Conduct of Civil Servants of the Russian Federation and Municipal Employees", adopted on December 23, 2010 by the Presidium of the Council under the President of the Russian Federation on combating corruption. 


\title{
REFERENCES
}

[1] Bakshtanovskij VI, Sogomonov JuV. Professional'naja jetika: sociologicheskie rakursy. V.I. Bakshtanovskij, Ju.V Sogomonov, editors. Moscow: SOCIS; 2005; (8): 3-13. (In Russ).

[2] Bojkov VJe. Professional'naja kul'tura i jetika gosudarstvennyh sluzhashhih. Sociologija vlasti. 1997; (4-5):14. (In Russ).

[3] Kodeks sluzhebnogo povedenija dolzhnostnyh lic: byt' ili ne byt'? Otchet o rabote "kruglogo stola". Chinovnik. 2003; (3):14-23. (In Russ).

[4] Komleva VV. Professional'naja jetika gosudarstvennyh sluzhashhih v uslovijah reformy gosudarstvennoj sluzhby. V.V. Komlev, editor. Sociologija vlasti. 2004; (1): 96-115. (In Russ).

[5] Constitution of Russian Federation. Available at http://constitution.kremlin.ru/. (In Russ).

[6] Moiseenko MV. Problema professional'noj nravstvennoj deformacii sotrudnikov pravoohranitel'nyh organov / Professional'naja jetika v sovremennom obshhestve. V.A. Cvyk, editor. Moscow: Jekon-inform; 2011. (In Russ).

[7] Mjagotin AV. Metamorfzy professional'noj morali gosudarstvennogo sluzhashhego. A.V. Mjagotin, editor. Vlast'. 2007; (12): 34-37. (In Russ).

[8] Tihomirov JuA, Talapino JeV. O kodifikacii i kodeksah. Zhurnal rossijskogo prava. 2003; (3): 47-54. (In Russ).

[9] Tsvyk VA, Tsvyk IV, Lapshin IY. Ethics of professional practice. 3rd International Multidisciplinary Scientific Conference On Social Sciences \& Arts. SGEM. 2016; 491.

[10] Federal Program № 261 of 10 March 2009. "Reformirovanie i razvitie sistemy gosudarstvennoj sluzhby Rossijskoj Federacii”. Available from: http://www.consultant.ru/document/cons doc_LAW_85601. (In Russ).

[11] Federal law № 79-FZ of 27 Julye 2004. "O sisteme gosudarstvennoj sluzhby Rossijskoj Federacii”, stat'ja 12. Available from: http://www.consultant.ru/document/cons_doc_LAW_48601/ 1813564cbe241552c9d71b038fc20dc395a186fb. (In Russ).

DOI: 10.22363/2313-2302-2017-21-3-346-352

\section{ЭТИКА ГОСУДАРСТВЕННОЙ СЛУЖБЫ}

\author{
В.С. Мухаметжанова \\ Российский университет дружбы народов \\ 117198, Москва, Россия, ул. Миклухо-Маклая, д. 6
}

\begin{abstract}
В статье рассматривается понятие этики государственных служащих как особого вида профессиональной этики. По мнению автора, в современном обществе очень остро стоит вопрос исследования проблем управления государственной службой и поиска механизмов повышения ее эффективности.

Специфика этики государственной службы определяется рядом факторов. Во-первых, особое предназначение самой государственной службы, закрепленной в Конституции РФ. Во-вторых, это особый социально-правовой статус государственных служащих. В-третьих, это ограничения и обязательства для граждан РФ при прохождении государственной службы. В-четвертых, формирование эффективного кадрового потенциала государственных служащих. И, наконец, осознание высокого уровня социальной ответственности чиновников за принимаемые решения в профессиональной деятельности.

Особое внимание в статье уделяется анализу этического кодекса, направленного на повышение эффективности выполнения государственными служащими своих должностных обязанностей. Знание и соблюдение этических принципов кодекса является ключевым в оценке качества их профес-
\end{abstract}


сиональной деятельности и служебного поведения. Утвержденные этические принципы службы задают общие ориентиры, обеспечивают нравственную целостность и жизнеспособность службы как системы в целом.

Ключевые слова: профессиональная этика, этика государственной службы, этический кодекс, этические принципы

\section{ЛИТЕРАТУРА}

[1] Бакитановский В.И., Согомонов Ю.В. Профессиональная этика: социологические ракурсы // СОЦИС. М., 2005. № 8. С. 3-13.

[2] Бойков В.Э. Профессиональная культура и этика государственных служащих // Социология власти. 1997. № 4-5. С. 14.

[3] Кодекс служебного поведения должностных лиц: быть или не быть? Отчет о работе «круглого стола» // Чиновникъ. 2003. № 3. С. 14-23.

[4] Комлева В.В. Профессиональная этика государственных служащих в условиях реформы государственной службы // Социология власти. 2004. № 1. С. 96-115.

[5] Конституция РФ. Режим доступа: http://constitution.kremlin.ru. Дата обращения 28.03.2017.

[6] Моисеенко М.В. Проблема профессиональной нравственной деформации сотрудников правоохранительных органов // Профессиональная этика в современном обществе: Сборник статей / под общ. ред. В.А. Цвыка. М.: Экон-информ, 2011.

[7] Мяготин A.B. Метаморфзы профессиональной морали государственного служащего // Власть. 2007. № 12. С. $34-37$.

[8] Тихомиров Ю.А., Талапино Э.В. О кодификации и кодексах // Журнал российского права. 2003. № 3. C. 47-54.

[9] Tsvyk V.A., Tsvyk I.V., Lapshin I.Y. Ethics of professional practice // 3rd International Multidisciplinary Scientific Conference On Social Sciences \& Arts, SGEM. 2016. P. 491.

[10] Федеральная программа № 261 «Реформирование и развитие системы государственной службы Российской Федерации». Консультант плюс. Режим доступа: http://www.consultant.ru/document/cons_doc_LAW_85601/.

[11] Ф3 № 79-Ф3 от 27 июля 2004 «О системе государственной службы Российской Федерации», статья 12, Консультант плюс. Режим доступа: http://www.consultant.ru/document/cons doc_LAW_48601/1813564cbe241552c9d71b038fc20dc395a186fb.

\section{Сведения об авторе:}

Мухаметжанова Винера Саяровна - кандидат социологических наук, ассистент кафедры этики факультета гуманитарных и социальных наук Российского университета дружбы народов; e-mail: mukhametzhanova_vs@rudn.university. 